University of Nebraska - Lincoln

DigitalCommons@University of Nebraska - Lincoln

Agronomy \& Horticulture -- Faculty Publications

Agronomy and Horticulture Department

December 2003

\title{
Soil organic carbon content and composition of 130-year crop, pasture and forest land-use managements
}

\author{
Dean A. Martens \\ USDA-ARS \\ Thomas E. Reedy \\ National Soil Survey Center, Lincoln, NE \\ David T. Lewis (retired) \\ University of Nebraska-Lincoln
}

Follow this and additional works at: https://digitalcommons.unl.edu/agronomyfacpub

Part of the Plant Sciences Commons

\footnotetext{
Martens, Dean A.; Reedy, Thomas E.; and Lewis, David T. (retired), "Soil organic carbon content and composition of 130-year crop, pasture and forest land-use managements" (2003). Agronomy \& Horticulture -- Faculty Publications. 124.

https://digitalcommons.unl.edu/agronomyfacpub/124
}

This Article is brought to you for free and open access by the Agronomy and Horticulture Department at DigitalCommons@University of Nebraska - Lincoln. It has been accepted for inclusion in Agronomy \& Horticulture -Faculty Publications by an authorized administrator of DigitalCommons@University of Nebraska - Lincoln. 


\title{
Soil organic carbon content and composition of 130-year crop, pasture and forest land-use managements
}

\author{
DEAN A. MARTENS*, THOMAS E. REEDY $\dagger$ and DAVID T. LEWIS \\ *USDA-ARS Southwest Watershed Research Center, 2000 E. Allen Road, Tucson, AZ 85719, USA, †National Soil Survey Center, \\ 100 Centennial Mall North, Room 152-MS 35, Lincoln, NE 68508-3866, USA, †University of Nebraska (retired), Lincoln, \\ NE 68508, USA
}

\begin{abstract}
Conversion of former agricultural land to grassland and forest ecosystems is a suggested option for mitigation of increased atmospheric $\mathrm{CO}_{2}$. A Sharpsburg prairie loess soil (fine, smectitic, mesic Typic Argiudoll) provided treatments to study the impact of long-term land use on soil organic carbon (SOC) content and composition for a 130-year-old cropped, pasture and forest comparison. The forest and pasture land use significantly retained more SOC, $46 \%$ and $25 \%$, respectively, compared with cropped land use, and forest land use increased soil $\mathrm{C}$ content by $29 \%$ compared with the pasture. Organic C retained in the soils was a function of the soil $\mathrm{N}$ content $(r=0.98, P<0.001)$ and the soil carbohydrate $(\mathrm{CH})$ concentration $(r=0.96, P<0.001)$. Statistical analyses found that soil aggregation processes increased as organic $C$ content increased in the forest and pasture soils, but not in the cropped soil. SOC was composed of similar percentages of CHs $(49 \%, 42 \%$ and $51 \%)$, amino acids $(22 \%, 15 \%$ and $18 \%)$, lipids $(2.3 \%, 2.3 \%$ and $2.9 \%)$ and unidentified C (21\%, 29\% and 27\%), but differed for phenolic acids (PAs) $(5.7 \%, 11.6 \%$ and $1.0 \%$ ) for the pasture, forest and cropped soils, respectively. The results suggested that the majority of the surface soil $\mathrm{C}$ sequestered in the long-term pasture and forest soils was identified as $\mathrm{C}$ of plant origin through the use of $\mathrm{CH}$ and PA biomarkers, although the increase in amino sugar concentration of microbial origin indicates a greater increase in microbial inputs in the three subsoils. The practice of permanent pastures and afforestation of agricultural land showed long-term potential for potential mitigation of atmospheric $\mathrm{CO}_{2}$.
\end{abstract}

Keywords: amino acids, carbohydrates, land-use change, lignin, lipids, organic C, phenolic acids

Received 23 December 2002; revised version received 20 August 2003 and accepted 08 September 2003

\section{Introduction}

Land-use change can alter land cover biomass and cause associated adjustment in carbon (C) stocks (Bolin \& Sukumar, 2000). C sequestration by afforestation or permanent grass vegetation in associated above-ground biomass increases are the only land-use managements accepted by the 1997 Kyoto Protocol to change global C budgets, but little is known on the effects of land-use change on the composition of stabilized soil $\mathrm{C}$ pools. Each soil has a $\mathrm{C}$ carrying capacity depending on the nature of vegetation, precipitation and temperature (Gupta \& Rao, 1994). The accumulation of soil organic

Correspondence: Dean A. Martens, tel. +520 6706380 ext. 156, fax + 520670 5550, e-mail: dmartens@tucson.ars.ag.gov matter (SOM) is a function of the amount of plant, animal and microbial inputs the soil has received in the past (Brady \& Weil, 1999) and the rate at which the biomass input decays (Jenkinson, 1977). The decay rate in the $\mathrm{C}$ cycle is related to the quantity and quality of the plant residue returned to the soil (Herman et al., 1977; Oades, 1988; Enriquez et al., 1993; Cheshire \& Chapman, 1996; Martens, 2000a), the soil type, especially the type and amount of clay minerals present (Amato \& Ladd, 1992), and management (Martens, 2000b). Understanding the impact of different land-use management on SOM content and composition is extremely important as soils may provide an immediate sink for atmospheric $\mathrm{CO}_{2}$ with proper management (Bruce et al., 1999), as research has noted that the process of soil $\mathrm{C}$ depletion with cropped land use can 
be reversed by utilization of pasture or reforestation land use (Guo \& Gifford, 2002; Murty et al., 2002; Six et al., 2002).

The equilibrium between $C$ inflows and outflows in soil is disturbed by land-use change until a new equilibrium is eventually reached in the new ecosystem (Guo \& Gifford, 2002). The equilibrium dynamics of C in different land-use options are a function of the plant residues returned to the soil, the litter $\mathrm{C}$ content, the amount of soluble vs. nonsoluble $\mathrm{C}$ components, the mineralization rates of the $\mathrm{C}$ components, the placement of above-ground vs. below-ground inputs and the degree of soil aggregate disturbance (Post \& Kwon, 2000). Soil organo-mineral complexes are predominantly found in association with clay and silt-sized fractions that may limit microbial access to plant $C$ within soil aggregates (Post \& Kwon, 2000; Bossuyt et al., 2002; Six et al., 2002). Much of the soil's original organic $\mathrm{C}$ loss with agricultural management can be attributed to reduced inputs of crop plant residue, increased mineralization rates of crop plant residue returned, and tillage effects that decrease the amount of physical protection for soil organic carbon (SOC) (Schlesinger, 1985; Post \& Mann, 1990; Davidson \& Ackerman, 1993). Guo \& Gifford (2002) summarized findings from 74 publications detailing that when landuse change decreased soil C content (e.g. pasture or prairie to cropland), the reverse land-use change (e.g. crop to pasture) resulted in nearly the same increased soil $\mathrm{C}$ contents. However, long-term data detailing the impact of land-use changes on SOC pools that may preferentially stabilize SOC are lacking.

Recent improvements in plant $\mathrm{C}$ analysis have identified between $85 \%$ and $90 \%$ of plant residue $C$ as carbohydrates $(\mathrm{CHs})$, protein or peptide amino acids (AAs), fatty acids (FAs)/lipids (LPs) and phenolic acids (PAs) of cell wall and lignin (Sommerville et al., 2000). Although little is known about the important change in critical C pools with land-use conversion that may preferentially stabilize SOC (Vesterdal et al., 2002; Six et al., 2002), determining the plant contribution to SOC pools with time and land-use management may provide details on stabilized soil $\mathrm{C}$ pools at land-use equilibrium. The study site investigated in this report is a unique setting as the documented cropping vs. forest managements introduced on a pasture have been in place for approximately 130 years with an available parcel of a mown, but never tilled or fertilized original pasture on the same soil type as a comparison. The objectives of this work were to detail the impact of pasture, cropped and forest land use on (1) the decline or increase in the total SOC and total N contents and (2) the composition of stabilized SOC and N pools with different land-use practices.

\section{Materials and methods}

\section{Study area}

The location of the study area is in southeast Nebraska about $27 \mathrm{~km}$ southeast of the town of Syracuse. The three sites occur within a delineation of the detailed soil map unit ShC - Sharpsburg silty clay loam (fine, smectitic, mesic Typic Argiudoll) on relatively stable ridgetops ( $2-5 \%$ slopes). These soils formed in loess of Medial Wisconsin age, about 28000-50 000 years before present (Reed \& Dreeszen, 1965). The current mean annual precipitation is about $80 \mathrm{~cm}, 70 \%$ of which falls during April-September (Sautter, 1982). Mean annual, winter and summer air temperatures are approximately $10.9^{\circ} \mathrm{C},-3.3^{\circ} \mathrm{C}$ and $23.9^{\circ} \mathrm{C}$, respectively. The elevation of the soils ranged from 344 to $352 \mathrm{~m}$ above sea level. The three kinds of management in this study were (1) a 130-year-old forest established on pasture, (2) a presentday conventional corn-soybean rotation established on pasture and (3) a never tilled or fertilized pasture.

The forest site (10 ha) was part of the original homestead established in 1866 to provide windbreak, fuel and fruits (Reedy, 1999). The land was covered originally by prairie grass and is currently under a variety of mostly deciduous trees, including black cherry (Prunus serotina), black locust (Robinia pseudoacacia), ash (Fraxinus spp.), American basswood (Tilia americana), eastern redcedar (Juniperus virginiana), hackberry (Celtis spp.), oak (Quercus spp.) and black walnut (Juglans nigra).

A variety of crops have been grown in the cultivated soil. First, it was red clover (Trifolium pratense) for the horses and dairy cows. Later, an oats (Avena sativa) wheat (Tritium aestivum) - corn (Zea mays) rotation was common until economics pushed oats out. In the late 1930s soybean (Glycine max) was added to the rotation (soybean-corn-wheat). Today's standard rotation is corn-soybean with plow and disk tillage as wheat was dropped from the rotation in the early 1990s.

Whereas the forest and the cropped field are less than $100 \mathrm{~m}$ apart, the pasture site is about $1.6 \mathrm{~km}$ eastsoutheast of the forest. Originally tall grass prairie, the site (97 ha) is now a mixture of cool- and warm-season grasses and forbs, and reflects a mixed short grass/tall grass pasture site.

\section{Sampling design}

There were three field sites with one replicate available for the forest and pasture land uses and a representative cropped soil was chosen near the forest site. A survey of each field was conducted, and sites for the three samplings were chosen that closely reflected the overall variability of the field(s). At each field site, three 
profiles of Sharpsburg soil were sampled to analyze land-use effects. For the pasture and cropped fields, two of the samples were collected with a Giddings ${ }^{\mathrm{TM}}$ (Giddings Machine Co., Fort Collins, CO, USA) soil probe $(10 \mathrm{~cm}$ diameter). To facilitate the collection of soil for bulk density analysis, the third soil sample was collected from a hand-dug pit. The three samples at the forest site were hand dug and described because the dense tree growth restricted Giddings probe access. Homogeneous soil horizons ( $0-33$ or $43 \mathrm{~cm}$ deep) were sampled for analysis of chemical and physical property differences (Table 1), because the pasture and forest horizons were narrower in the upper part of the pedon and generally increased thickness of horizons with depth compared with the cropped soil. This sampling protocol was used for the pasture and forest land use to retain the integrity of information conveyed by the natural soil compared with the homogeneous plow horizon in the cropped soil.

Due to the unique set of circumstances for the forest and pasture sites, replication was not established during the 1860s. Other farms within the same soil type do not have the continuous ownership, the large pasture remnant, the pasture to forest conversion or the detailed records that are available for the agricultural land use on this farm. In order to compare $\mathrm{C}$ and $\mathrm{N}$ ecosystems, the pseudoreplicates were first analyzed for variance within treatments and then the within variance standard deviations were compared with the between variance deviations to determine if potential treatment differences exist. It is important to understand that due to the pseudoreplication of field sites, the differences determined by the ANOVA analyses (Minitab 13.32, Minitab, Inc., State College, PA, USA) may suffer from both type I and type II errors. Significance was determined at the $P \leq 0.05 \%$ level.

\section{Chemical analyses}

Analyses were made on air-dry soil material that passed through a $2 \mathrm{~mm}$ sieve. Organic $\mathrm{C}$ and total $\mathrm{N}$ contents were determined by dry combustion with a PerkinElmer $2400 \mathrm{C} / \mathrm{H} / \mathrm{N}$ analyzer (Perkin-Elmer, Inc., Fullerton, CA, USA). Soil $\mathrm{pH}$ was determined with a glass electrode, using a $1: 1$ soil to water suspension, bulk density was determined according to Blake \& Hartge (1986), and particle size distribution was determined on the sieved material (Gee \& Bauder, 1986). Aggregate stability was determined on the fraction of soil remaining on a $2 \mathrm{~mm}$ sieve after water emersion (80 oscillations $\mathrm{min}^{-1}$ ) and sand dispersion with a modified Yoder apparatus (Kemper \& Rosenau, 1986).

Extractable $\mathrm{CH}$ concentration was measured by acid extraction and ion chromatography with pulsed am- perometric detection of individual monosaccharides (Martens \& Loeffelmann, 2002). Briefly, $100 \mathrm{mg}$ soil was treated with $6 \mathrm{M} \mathrm{H}_{2} \mathrm{SO}_{4}$ for $0.5 \mathrm{~h}$, adjusted to $1.5 \mathrm{M}$ $\mathrm{H}_{2} \mathrm{SO}_{4}$ and autoclaved at $121^{\circ} \mathrm{C}(104 \mathrm{kPa})$ for $0.5 \mathrm{~h}$, titrated to $\mathrm{pH} 4-5$ with $5 \mathrm{M} \mathrm{KOH}$, centrifuged to remove precipitate, and an aliquot was diluted for analysis.

AA composition of digested soil proteins or peptides was measured by acid extraction and ion chromatography with pulsed amperometric analysis of the individual AAs and amino sugars (ASs) (Martens \& Loeffelmann, 2003). Briefly, $250 \mathrm{mg}$ soil was autoclaved $\left(136^{\circ} \mathrm{C}, 134 \mathrm{kPa}\right)$ for $1 \mathrm{~h}$ with $2 \mathrm{~mL} 4 \mathrm{M}$ methanesulfonic acid (2 $\mathrm{mg}$ tryptamine $\left.\mathrm{mL}^{-1}\right)$, neutralized to $\mathrm{pH} 5$ with $5 \mathrm{M} \mathrm{KOH}$, centrifuged to remove precipitate, and an aliquot was diluted for analysis.

The monosaccharides and AAs were separated on a Dionex DX-500 (Dionex Corp., Sunnyvale, CA, USA) ion chromatograph equipped with a CarboPac PA10 column ( $250 \mathrm{~mm} \times 2 \mathrm{~mm}$ i.d.) for monosaccharide analysis and an AminoPac PA10 column (Dionex Corp., Sunnyvale, CA, USA) $(250 \mathrm{~mm} \times 2 \mathrm{~mm}$ i.d. $)$ for AA and AS analysis. Separation was achieved with a $\mathrm{NaOH}$ gradient (5-80 mM) for monosaccharides and a $\mathrm{NaOH}-$ $\mathrm{Na}$ acetate gradient $(30-80 \mathrm{~mm} \mathrm{NaOH} ; 0-500 \mathrm{~mm} \mathrm{Na}$ acetate) for AAs. Ammonium released during the soil protein extraction was determined by steam distillation (Keeney \& Nelson, 1982).

Ester-linked PAs present in primary cell walls of plant litter in soil $(2 \mathrm{~g})$ were extracted with $5 \mathrm{~mL} 1 \mathrm{M}$ $\mathrm{NaOH}$ for $16 \mathrm{~h}$ on a reciprocal shaker at $30^{\circ} \mathrm{C}$ as described by Martens (2002b). After extraction, the sample was centrifuged and the supernatant was placed in a disposable glass test tube and heated at $90{ }^{\circ} \mathrm{C}$ for $2 \mathrm{~h}$ to release the conjugated PAs (Whitehead et al., 1983). The heated extract was then cooled, titrated with $4 \mathrm{M} \mathrm{HCl}$ to $\mathrm{pH}<2.0$, diluted to $10 \mathrm{~mL}$, and centrifuged to remove the precipitate.

Lignin PAs were determined by cupric oxide digestion on the soil residue following ester-linked PA extraction $(1 \mathrm{M} \mathrm{NaOH})$. Cupric oxide ( $0.5 \mathrm{~g})$ with $5 \mathrm{~mL} 2 \mathrm{M} \mathrm{NaOH}$ were added to the residue soil and heated to $140{ }^{\circ} \mathrm{C}$ for $2 \mathrm{~h}$ (Chen, 1992). After extraction, the sample was centrifuged, washed with $5 \mathrm{~mL}$ water and the supernatants were acidified with $4 \mathrm{M} \mathrm{HCl}$ to $\mathrm{pH}<2.0$, diluted to $10 \mathrm{~mL}$, and centrifuged to remove the precipitate.

Aliquots of the ester-linked and lignin extractions were passed through a Varian Bond Elut ${ }^{\mathrm{TM}}$ PPL solid phase extraction tube (Varian Assoc., Harbor City, CA, USA) to eliminate interferences. The extraction tubes were dried under a stream of air and the phenolic compounds were eluted with $1 \mathrm{~mL}$ of ethyl acetate into gas chromatography autosampler vials. The phenolic compounds ( $1 \mu \mathrm{L}: 10: 1$ split) were then analyzed for composition with a Hewlett-Packard 6890 gas 
chromatograph (Hewlett-Packard, Palo Alto, CA, USA) equipped with an HP-5 (5\% cross-linked phenylmethyl siloxane) capillary column $(30 \mathrm{~m}$ length, $0.32 \mathrm{~mm}$ column i.d., $0.25 \mu \mathrm{m}$ film thickness) and detected with a flame ionization detector (Martens, 2002b). The following conditions were employed for PA separation: injector temperature, $230^{\circ} \mathrm{C}$; temperature ramp, $70^{\circ} \mathrm{C}$ for $2 \mathrm{~min}$ and then ramped to $250^{\circ} \mathrm{C}$ at $10^{\circ} \mathrm{C} \mathrm{min}{ }^{-1}$; detector temperature, $250^{\circ} \mathrm{C}$.

LP material (neutral hydrocarbons and FAs) was extracted from the soil samples $(2 \mathrm{~g})$ with $10 \mathrm{~mL}$ of a monophasic mixture of methanol, chloroform and citrate buffer $(2: 1: 0.8 \mathrm{v} / \mathrm{v} / \mathrm{v})$ for $2.5 \mathrm{~h}$ at ambient temperatures (Frostegard et al., 1993). The solution and solids were separated by centrifugation and the supernatants were transferred into glass test tubes with Teflon lined caps. The samples were split into two phases by adding chloroform and buffer; then the methanol-buffer phase was removed and the chloroform phase was dried under a stream of air. The FAs present in the sample were methylated by addition of $1 \mathrm{~mL}$ methanol, chloroform and concentrated $\mathrm{HCl}(10: 1: 1 \mathrm{v} / \mathrm{v} / \mathrm{v})$, and the mixture was heated overnight at $60^{\circ} \mathrm{C}$ (Zelles \& Bai, 1993). The neutral and methylated compounds were isolated by addition of $0.5 \mathrm{~mL}$ chloroform and $4 \mathrm{~mL}$ water. The chloroform phase was then removed after centrifugation for analysis with a Hewlett-Packard 6890 gas chromatograph equipped with an HP-5 (5\% crosslinked phenylmethyl siloxane) capillary column $(30 \mathrm{~m}$ length, $0.32 \mathrm{~mm}$ column i.d., $0.25 \mu \mathrm{m}$ film thickness) and detected with a flame ionization detector. The LP materials are designated as the total number of $\mathrm{C}$ atoms followed by the number of double bonds and the number following shows the position of the double bonds nearest the carboxyl end of the molecule.

To obtain a total content of the $\mathrm{C}$ and $\mathrm{N}$ content and the individual components of $\mathrm{C}$ and $\mathrm{N}$ content for the analyzed profiles, a weighted average of these parameters to a depth of $33 \mathrm{~cm}$ based on the following equation was calculated:

$$
\begin{aligned}
\text { weighted content }= & \sum\left(T \times I\left(\mathrm{mgg}^{-1}\right)\right. \\
& \left.\times \text { bulkdensity }\left(\mathrm{gcm}^{-3}\right)\right) / \sum \mathrm{Ti}
\end{aligned}
$$

where $T$ is the thickness of the horizon, $I$ is the quantity of the property of interest and $\mathrm{Ti}$ is the total thickness $(33 \mathrm{~cm})$.

\section{Results and discussion}

\section{Soil profile changes}

Soil C cycling is due to the complex interactions between the chemical composition of plant residue and the biological and physical processes in soils. In order to understand soil $\mathrm{C}$ composition changes among the three land-use sites in the study area, one assumption was that any differences in the measured properties were the result of land-use effects and not due to differences in the original parent material. The particle size distribution, coarse silt distribution, fine silt to coarse silt ratios, and ratio of resistant to less resistant mineral analysis were consistent with the assumption that the parent material for the three sites were similar with depth and ages of parent material and clay content (Reedy, 1999). Since soil clay content is a very important factor controlling the accumulation of SOC (Christensen, 1992), it is pertinent to have constant clay content across the treatments. The higher $\mathrm{pH}$ values for the surface of the forested soil may reflect the proximity of a crushed limestone road in place since 1936 (Table 1).

As expected, both the forest and the pasture soils had significantly greater organic $\mathrm{C}$ content, total $\mathrm{N}$ content and aggregate stability through the sampled depths compared with the cropped soil (Table 1). Figure 1a shows the relationship of soil $\mathrm{N}$ with the soil $\mathrm{C}$ content in the different ecosystems investigated here. The slope of the regression line found for the total $\mathrm{N}$ and organic $C$ relationship for the three land uses equaled 11.36 $(r=0.98, P<0.001)$, although the cropped soil had a lower $\mathrm{C} / \mathrm{N}$ ratio than the forest and pasture through the sampled depths (Table 1). The organic $C$ content of the forest soil suggests that a mix of trees established on pasture can accumulate greater amounts of SOC than the pasture in addition to the $\mathrm{C}$ accumulated in the above-ground plant biomass.

The importance of $\mathrm{N}$ for increasing the amount of plant biomass and subsequent litter inputs in ecosystems is well known. Since the forest and pasture have never received documented $\mathrm{N}$ fertilizers, the increase in $\mathrm{C}$ and $\mathrm{N}$ is apparently a function of $\mathrm{N}$ conserved within the soil cycles and possible atmospheric $\mathrm{N}$ deposition. Neely et al. (1991) reported that chestnut oak (Quercus prinus L.) residue decomposing in soil litter bags accumulated significant amounts of soil $\mathrm{N}$, in addition to the residue $\mathrm{N}$ content during a 160 days incubation. The microbial immobilization or conservation of soil $\mathrm{N}$ by decaying residues with a high $\mathrm{C} / \mathrm{N}$ ratio may explain how over time higher soil $\mathrm{N}$ contents can be found in soils receiving no commercial fertilizers. Microbial immobilization may not be the only process stabilizing soil N, as Davidson et al. (2003) recently detailed soil mineral $\mathrm{N}$ immobilization via an abiotic mechanism by the interaction of reduced Fe converting $\mathrm{NO}_{3}^{-}$to $\mathrm{NO}_{2}^{-}$with a resulting nitration involving the aromatic ring component of dissolved organic $\mathrm{C}$.

The consistent nature of $\mathrm{C} / \mathrm{N}$ ratios (10-12) of SOM has long been recognized; however, not fully appreciated are the practical and mechanistic implications of 
Table 1 Properties of soils tested

\begin{tabular}{|c|c|c|c|c|c|c|c|c|c|c|}
\hline \multirow[b]{2}{*}{ Land use } & \multirow[b]{2}{*}{$\begin{array}{l}\text { Depth } \\
(\mathrm{cm})\end{array}$} & \multirow[b]{2}{*}{ Horizon } & \multirow[b]{2}{*}{$\mathrm{pH}$} & \multicolumn{6}{|l|}{$\mathrm{g} \mathrm{kg}^{-1}$} & \multirow{2}{*}{$\begin{array}{l}\frac{\mathrm{g} \mathrm{cm}^{-3}}{\text { Bulk }} \\
\text { density }\end{array}$} \\
\hline & & & & $\begin{array}{l}\text { Organic } \\
\text { C }\end{array}$ & $\begin{array}{l}\text { Total } \\
\mathrm{N}\end{array}$ & $\begin{array}{l}\mathrm{C} / \mathrm{N} \\
\text { ratio }\end{array}$ & $\begin{array}{l}\text { Aggregate } \\
\text { stability }\end{array}$ & Silt & Clay & \\
\hline \multirow[t]{3}{*}{ Forest } & $0-4$ & A1 & 6.9 & 76.1 & 6.25 & 12.2 & 750 & 658 & 312 & 1.45 \\
\hline & $4-8$ & A2 & 6.8 & 48.8 & 4.38 & 11.1 & 647 & 665 & 314 & 1.21 \\
\hline & $8-33$ & $\mathrm{~A} 3$ & 6.5 & 24.6 & 2.31 & 10.6 & 380 & 644 & 333 & 1.30 \\
\hline \multirow[t]{3}{*}{ Pasture } & $0-5$ & A1 & 5.4 & 46.1 & 3.81 & 12.1 & 880 & 667 & 310 & 1.11 \\
\hline & 5-13 & $\mathrm{A} 2$ & 5.3 & 33.2 & 3.09 & 10.7 & 880 & 670 & 311 & 1.24 \\
\hline & $13-33$ & A3 & 5.3 & 22.2 & 2.22 & 10.0 & 490 & 621 & 363 & 1.37 \\
\hline \multirow[t]{3}{*}{ Crop } & $0-20$ & Ap1 & 5.2 & 19.1 & 1.82 & 10.5 & 30 & 630 & 349 & 1.35 \\
\hline & $20-24$ & Ap2 & 5.0 & 16.9 & 1.84 & 9.18 & 155 & 628 & 351 & 1.40 \\
\hline & $24-38$ & Bt1 & 5.7 & 14.0 & 1.52 & 9.21 & 120 & 571 & 411 & 1.45 \\
\hline \multirow{3}{*}{$\mathrm{LSD}_{5 \%}$} & Depth 1 & & ND & 18.1 & 0.81 & ND & 15.2 & ND & ND & ND \\
\hline & Depth 2 & & ND & 6.67 & 0.28 & ND & 21.9 & ND & ND & ND \\
\hline & Depth 3 & & ND & 3.07 & 0.30 & ND & 29.5 & ND & ND & ND \\
\hline
\end{tabular}

ND, not determined.

(a)

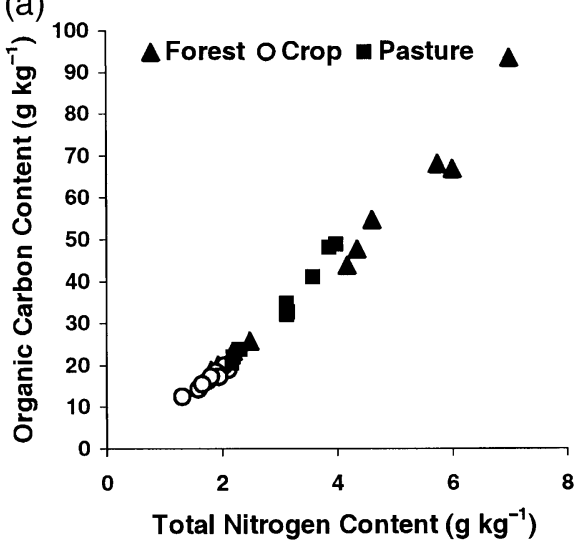

(b)

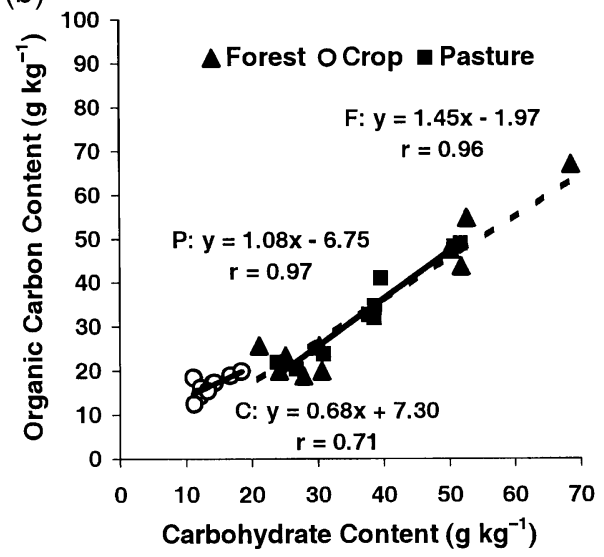

(c)

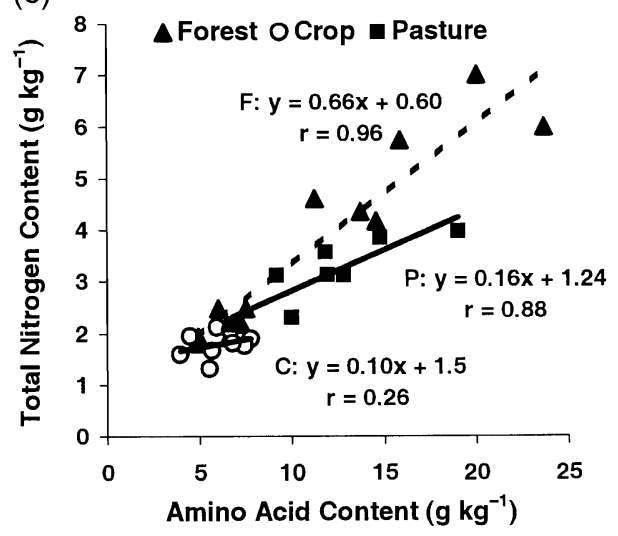

(d)

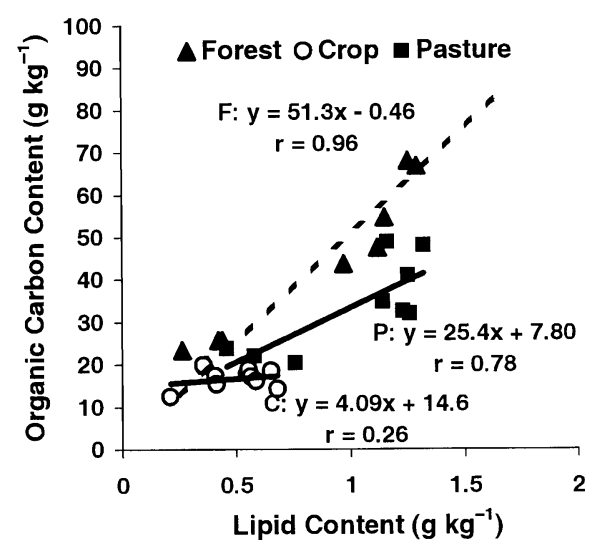

Fig. 1 The relationship between soil (a) total nitrogen content and organic carbon content, (b) carbohydrate concentration and organic carbon content, (c) amino acid concentration and total nitrogen content and (d) lipid concentration and organic carbon content for the different land uses. 
this relationship for $\mathrm{C}$ stabilization. It is evident from Fig. 1a that stabilized SOC content will not increase without a concomitant increase in the soil $\mathrm{N}$ content. The highly correlated $\mathrm{C}$ and $\mathrm{N}$ relationship implies the possibility of two different mechanisms: (1) The majority of SOM is composed of N-rich C compounds such as glycoproteins, e.g., glomalin, as measured by a qualitative reactive antibiody test (Wright \& Anderson, 2000) or (2) Remnants of plant material with high C/N ratios in various stages of decomposition remain in soil that immobilize soil N. While no quantitative determination of the importance of glomalin to SOC content has been published, the results reported here support the immobilization of soil $\mathrm{N}$ in the forest or pasture land uses by inputs of high $\mathrm{C} / \mathrm{N}$ ratio plant residues and possible abiotic mechanisms.

Research has shown that plant residue additions in forest and permanent pasture land-use systems can increase soil aggregation and, concomitantly, soil C content (Bossuyt et al., 2002). The loss of $C$ with cropped land use has been linked to soil disturbance (Beare et al., 1994; Bremer et al., 1994) and change in plant litter C composition (Martens 2000a, 2002a). Soil aggregate stability was much greater in the pasture and forest soils compared with the cropped soil (Table 1). The forest soil was highly aggregated in the soil surface $(0-5 \mathrm{~cm})$ that received the majority of the plant litter with decreased aggregate stability with soil depth (Table 1). The cropped soil had the lowest water-stable aggregate percentage of the land-use systems and soil stability increased slightly with depth below the plow zone. The increase in aggregation in the $20-24 \mathrm{~cm}$ cropped soil depth may be due to the accumulation of labile subsurface $C$ in tillage-based cropped systems as reported by Bossuyt et al. (2002).

Most of the SOC originates from plant residue additions and, during decomposition, plant debris becomes intimately associated with inorganic soil particles and stabilized within soil organo-mineral complexes (Post \& Kwon, 2000). Organo-mineral complexes are predominantly found in association with clay and silt-sized fractions that may limit microbial access to plant $\mathrm{C}$ when organo-minerals complex as soil aggregates (Post \& Kwon, 2000; Bossuyt et al., 2002; Six et al., 2002). A significant trend between aggregate stability and organic C content was noted in the highly aggregated forest $(r=0.75 ; P<0.05)$ and pasture soils $(r=0.80 ; P<0.05)$, but the aggregate- $C$ trend was not evident in the cropped soil $(r=-0.64)$. The rate of SOC cycling has been linked to aggregate formation (Beare et al., 1994; Six et al., 2001), and the low aggregate stability in the cropped soil supports previous research showing that organic $C$ and aggregate stability are greatly impacted by tillage-based cropping systems (Biederbeck et al., 1994; Bremer et al.,1994). With plant soluble and nonsoluble $\mathrm{C}$ additions being stabilized in soil physical fractions (Post \& Kwon, 2000; Six et al., 2001), soil analysis for organic $\mathrm{C}$ compounds of plant origin may identify the major pools of the SOC that accumulate or decline with land-use change.

\section{Soil C composition with land-use changes}

The loss of SOC content by conversion of native vegetation to agricultural is well documented (Capriel et al., 1992; Murty et al., 2002), but little is known about the change in soil $\mathrm{C}$ composition with change from cropped to pasture or afforestation management.

\section{Soil $\mathrm{CHs}$}

$\mathrm{CHs}$ as plant cellulose and hemicellulose compose from $22 \%$ to $60 \%$ of the C content of different plants (Martens \& Loeffelmann, 2002) and constitute the greatest source of organic $\mathrm{C}$ to the biosphere. In the surface horizons, the pasture and the forest soils had statistically similar concentrations of extractable $\mathrm{CH}$ material, but the surface horizon $\mathrm{CHs}$ in the pasture and forest land use were three to five times greater than the $\mathrm{CH}$ concentration in the cropped soil (Table 2). The forest and pasture soil $\mathrm{CH}$ concentrations were greater through the profile compared with the cropped soil (Table 2). The change in $\mathrm{CH}$ concentration with depth noted for the pasture and forest soils was not evident in the cropped soil homogenized by tillage. In five out of the six depths sampled for the forest and pasture soils, glucose concentration comprised $>50 \%$ of the total $\mathrm{CH}$ concentration, which reflected the dominant contribution of glucose in the cellulose and hemicellulose plant fractions added to the soils. Glucose accounted for only about $40 \% \mathrm{CH}$ material in the top $24 \mathrm{~cm}$ for the cropped soil, but increased to $>60 \%$ of the $\mathrm{CH}$ in the $24-38 \mathrm{~cm}$ depth.

$\mathrm{CHs}$ are the major $\mathrm{C}$ contribution to terrestrial soils and provide the major source of energy for microbial processes in soil. Figure $1 b$ shows that regression analysis found significant trends for soil $\mathrm{CH}$ concentration and SOC content in the pasture $(r=0.95, P<0.001)$ and forest soils $(r=0.91, P<0.01)$, but no significance was noted for the cropped soil $(r=0.71)$. Indeed, as with the organic $\mathrm{C}$ and total $\mathrm{N}$ graph (Fig. 1a), the $y$-intercept for the relationship between $\mathrm{CH}$ concentration and organic $C$ content (Fig. 1b) approximated zero $(y=1.06 x+0.14, r=0.96, P<0.001)$, implying that SOC directly increased as $\mathrm{CH}$ increased. The origin of soil $\mathrm{CHs}$ has been suggested to be a mix of plant and microbial compounds, yet long-term soil incubations with ${ }^{14} \mathrm{C}$-glucose or ${ }^{14} \mathrm{C}$-labeled plant residue resulted in no microbially mediated transfer of the ${ }^{14} \mathrm{C}$-label to other soil monosaccharides (Sowden \& Ivarson, 1962; 
Table 2 Major monosaccharide profiles for the different land-use systems $(n=3)$

\begin{tabular}{|c|c|c|c|c|c|c|c|c|c|}
\hline \multirow[b]{2}{*}{ Land use } & \multirow[b]{2}{*}{ Depth } & \multicolumn{8}{|l|}{$\mathrm{g} \mathrm{kg}^{-1}$} \\
\hline & & Fucose & Ara & Rhamnose & Gal & Glucose & Xylose & Mannose & Total \\
\hline \multirow[t]{3}{*}{ Forest } & $0-4$ & 0.50 & 7.88 & 2.03 & 11.1 & 40.6 & 2.02 & 11.2 & $75.3 \pm 7.7$ \\
\hline & $4-8$ & 0.33 & 5.93 & 1.42 & 7.46 & 27.5 & 1.28 & 7.59 & $51.5 \pm 0.9$ \\
\hline & $8-33$ & 0.21 & 3.85 & 0.68 & 4.66 & 10.8 & 0.87 & 4.44 & $25.5 \pm 3.0$ \\
\hline \multirow[t]{3}{*}{ Pasture } & $0-5$ & 0.34 & 5.00 & 1.09 & 7.61 & 32.1 & 2.57 & 7.61 & $56.3 \pm 6.7$ \\
\hline & $5-13$ & 0.29 & 4.23 & 0.90 & 6.26 & 17.7 & 1.74 & 7.71 & $38.3 \pm 0.5$ \\
\hline & $13-33$ & 0.24 & 3.23 & 0.67 & 4.72 & 21.1 & 1.10 & 5.05 & $27.2 \pm 3.5$ \\
\hline \multirow[t]{3}{*}{ Crop } & $0-20$ & 0.19 & 2.33 & 0.34 & 2.66 & 6.26 & 0.60 & 3.17 & $15.5 \pm 3.8$ \\
\hline & $20-24$ & 0.11 & 2.21 & 0.33 & 2.56 & 5.11 & 0.47 & 2.80 & $13.6 \pm 1.1$ \\
\hline & $24-38$ & 0.10 & 2.12 & 0.33 & 2.23 & 12.4 & 0.41 & 2.90 & $19.8 \pm 0.9$ \\
\hline \multirow[t]{3}{*}{$\mathrm{LSD}_{5 \%}$} & Depth 1 & 0.17 & 1.43 & 0.61 & 2.83 & 21.9 & 0.80 & 6.83 & 26.5 \\
\hline & Depth 2 & 0.49 & 1.03 & 0.36 & 0.91 & 4.79 & 0.22 & 2.04 & 2.56 \\
\hline & Depth 3 & 0.08 & 0.67 & 0.14 & 0.99 & 6.29 & 0.27 & 1.49 & 8.98 \\
\hline
\end{tabular}

Ara, arabinose; Gal, galactose; Total, sum of all monosaccharides detected as mean \pm standard deviation.

Table 3 Major amino acid profiles for the different land-use systems $(n=3)$

\begin{tabular}{|c|c|c|c|c|c|c|c|c|c|c|c|}
\hline \multirow[b]{2}{*}{ Land use } & \multirow[b]{2}{*}{ Depth } & \multicolumn{10}{|c|}{$\mathrm{g} \mathrm{kg}^{-1}$} \\
\hline & & Arg & Lys & Gal & Glu & Thr & Leu & Ala & Gln & Cys & Total \\
\hline \multirow[t]{3}{*}{ Forest } & $0-4$ & 1.35 & 1.55 & 1.29 & 1.90 & 1.34 & 0.56 & 1.73 & 1.45 & 0.48 & $23.7 \pm 3.9$ \\
\hline & $4-8$ & 1.11 & 0.98 & 0.92 & 1.45 & 0.63 & 0.25 & 0.80 & 0.66 & 0.28 & $14.5 \pm 1.7$ \\
\hline & $8-33$ & 1.11 & 0.67 & 0.56 & 1.06 & 0.19 & 0.15 & 0.39 & 0.16 & 0.15 & $7.50 \pm 0.8$ \\
\hline \multirow[t]{3}{*}{ Pasture } & $0-5$ & 2.07 & 1.29 & 0.94 & 1.79 & 0.57 & 0.30 & 1.03 & 1.07 & 0.33 & $18.9 \pm 3.6$ \\
\hline & $5-13$ & 1.33 & 1.05 & 0.69 & 1.47 & 0.37 & 0.17 & 0.60 & 1.86 & 0.29 & $11.3 \pm 1.9$ \\
\hline & $13-33$ & 0.64 & 0.88 & 0.59 & 1.33 & 0.27 & 0.07 & 0.40 & 1.04 & 0.21 & $10.0 \pm 1.8$ \\
\hline \multirow[t]{3}{*}{ Crop } & $0-20$ & 0.75 & 0.82 & 0.52 & 1.01 & 0.20 & 0.10 & 0.34 & 0.82 & 0.16 & $7.78 \pm 0.9$ \\
\hline & $20-24$ & 0.50 & 0.71 & 0.47 & 0.93 & 0.18 & 0.08 & 0.31 & 0.80 & 0.12 & $7.73 \pm 1.5$ \\
\hline & $24-38$ & 0.65 & 0.63 & 0.42 & 0.84 & 0.14 & 0.05 & 0.22 & 0.97 & 0.12 & $5.07 \pm 0.9$ \\
\hline \multirow[t]{3}{*}{$\mathrm{LSD}_{5 \%}$} & Depth 1 & 0.80 & 0.55 & 0.36 & 0.38 & 0.34 & 0.10 & 0.68 & 0.15 & 0.53 & 6.15 \\
\hline & Depth 2 & 0.42 & 0.27 & 0.09 & 0.33 & 0.10 & 0.23 & 0.12 & 0.09 & 0.59 & 3.82 \\
\hline & Depth 3 & 0.26 & 0.36 & 0.09 & 0.26 & 0.20 & 0.06 & 0.12 & 0.08 & 0.62 & 2.63 \\
\hline
\end{tabular}

Arg, arginine; Lys, lysine; Gal, galactosamine; Glu, glucosamine; Thr, threonine; Ala, alanine; Glu, glutamic acid; Total, sum of all amino acids detected as mean \pm standard deviation.

Oades \& Wagner, 1971). Martens \& Frankenberger (1992) also found that glucose pulses to soil failed to show the microbial synthesis of monosaccharides that would be present in microbial polysaccharides, and these results suggest that the majority of the soil $\mathrm{CH}$ concentration was not microbial in origin, but reflect $\mathrm{CHs}$ present in stabilized plant residues.

\section{Soil AAs}

The majority of plant $\mathrm{N}$ that is cycled through soil is present as proteins, and proteins may constitute up to $20 \%$ of the plant C content (Sommerville et al., 2000). The AA concentration in the forest and pasture soil surface horizons was greater than that in cropped soil, with a consistent trend of decreasing AA concentration with depth in the pasture and forest sites sampled (Table 3). The decreased AA concentration with depth was not evident in the cropped soil because of the tillage factor. Unlike the $\mathrm{CHs}$, for which glucose was the major monosaccharide present, the protein and nonprotein AAs were present in a rather uniform concentration in the soils tested. Glucosamine and galactosamine were the major ASs present in the soils, with significantly greater concentrations found in the forest and pasture soils compared with the cropped soil. ASs are not present in plant residue, so the detection of a large AS component of the total AAs in forest (average 
$17 \%$ ), pasture (average 18\%) and cropped soils (average $20 \%$ ) represents an important contribution from microbial activity, fungal hyphae or insect exoskeletons (nonplant soil $\mathrm{C}$ inputs) to soil organic $\mathrm{N}$ pools. The average increase in the glucosamine concentration of the AA fraction with depth from $10.1 \%$ in the surface soil to $14.7 \%$ at the deeper depths suggests a change from more plant remnants remaining at the surface to a $C$ signature with a greater microbial input at the deeper depths.

Approximately $95 \%$ of mature plant $\mathrm{N}$ is identified as AAs and the majority of soil organic $\mathrm{N}$ is also identified as AAs or ASs (Martens \& Loeffelman, 2003). The dominance of AAs as the source of organic $\mathrm{N}$ in nature suggests that soil AA analysis may account for a large portion of soil $\mathrm{N}$ content. Indeed, a strong relationship between AA concentration and total $\mathrm{N}$ content (Fig. 1c) was found for the forest soil $(r=0.89, P<0.01)$ and the pasture soil $(r=0.96, P<0.001)$, but was not noted for the cropped soil $(r=0.26)$. The apparent lack of significant relationships between the $\mathrm{CH}$ concentration and organic C content $(r=0.71)$ and AA concentration and total $\mathrm{N}$ content in the cropped soil confirms the previous findings that plant residue $\mathrm{C}$ contributions to soil $\mathrm{C}$ content are negated by the act of tillage (Capriel et al., 1992; Biederbeck et al., 1994; Murty et al., 2002).

\section{Soil LPS}

LPs are present in all living cells and are present in soils as partially decomposed and undecomposed plant material and microbial LPs (Wang et al., 1971). A large variety of FAs were found in the soils under the different land-use types (Table 4). The actual number of
LPs quantified ranged from 22 in the cropped soil to $\geq 35$ in the forest and pasture soil. In the majority of soil samples, palmitic acid (C16:0) was found in the greatest concentration and C16:0 concentrations were significantly higher in the pasture and forest soils compared with the cropped soil. The pasture and forest soils had the highest levels of linoleic and linolenic acids (C18:2n9,12 and C18:3n9,12,15) in the surface horizons. With each FA, the general trend in the forest and pasture soils was that highest LP concentrations were present in the surface horizons with a decrease in concentration with depth, while the cropped soil showed little FA concentration change with depth.

Since cell cultures have been shown to actively metabolize cell membrane components during growth (White et al., 1979), certain extractable LPs have been suggested to provide an estimate of microbial biomass (Zelles et al., 1995) such as for C16:0 (palmitic acid) (Baird \& White, 1985; Zelles et al., 1992) and C18:2 or 3 as a marker of fungal populations (Frostegard et al., 1993; Arao, 1999). The FAs of proposed fungal origin were most pronounced in the surface horizons of the different land-use systems. Figure $1 d$ shows a significant relationship for the LP material isolated from the forest soils and the organic C content $(r=0.96$; $P<0.001)$. The pasture soil LP concentration also had a strong relationship $(r=0.78 ; P<0.05)$, but with a $y$-intercept at $8 \mathrm{~g}$ organic $\mathrm{C}$ that may reflect a greater input of LPs by roots in the pasture soil. The LP concentration of the cropped soil was not statistically correlated with organic C content $(r=0.26)$, perhaps due to the deleterious effects of tillage on the numbers and diversity of microbial populations (Follett \& Schimel, 1989).

Table 4 Major lipid profiles for the different land uses $(n=3)$

\begin{tabular}{|c|c|c|c|c|c|c|c|c|c|}
\hline \multirow[b]{2}{*}{ Land use } & \multirow[b]{2}{*}{ Depth } & \multicolumn{8}{|c|}{$\mathrm{mg} \mathrm{kg}^{-1}$} \\
\hline & & $\mathrm{C} 16: 0$ & C18:3n6 & $\mathrm{C} 18: 2 \mathrm{n} 6$ & C18:0 & C22:1n9 & C23:1 & C24:0 & Total \\
\hline \multirow[t]{3}{*}{ Forest } & $0-4$ & 85.20 & 75.75 & 35.00 & 33.03 & 60.62 & 23.99 & 106.4 & $1430 \pm 201$ \\
\hline & $4-8$ & 70.95 & 59.71 & 50.08 & 50.77 & 46.86 & 55.12 & 15.96 & $1210 \pm 279$ \\
\hline & $8-33$ & 22.22 & 19.06 & 10.32 & 15.47 & 15.43 & 17.57 & 18.14 & $370.8 \pm 103$ \\
\hline \multirow[t]{3}{*}{ Pasture } & $0-5$ & 72.76 & 92.80 & 27.13 & 17.61 & 28.98 & 34.27 & 56.94 & $1244 \pm 78$ \\
\hline & 5-13 & 76.57 & 115.7 & 25.86 & 31.21 & 34.58 & 26.77 & 30.54 & $1144 \pm 88$ \\
\hline & $13-33$ & 38.45 & 78.88 & 18.56 & 11.91 & 14.92 & 23.88 & 25.81 & $599.0 \pm 148$ \\
\hline \multirow[t]{3}{*}{ Crop } & $0-20$ & 32.49 & 27.22 & 8.256 & 24.11 & 15.14 & 18.42 & 29.76 & $521.4 \pm 151$ \\
\hline & $20-24$ & 30.29 & 28.21 & 17.32 & 28.30 & 22.48 & 32.22 & 22.21 & $525.5 \pm 99$ \\
\hline & $24-38$ & 27.17 & 26.62 & 14.26 & 23.71 & 13.07 & 27.52 & 16.06 & $427.0 \pm 224$ \\
\hline \multirow[t]{3}{*}{$\mathrm{LSD}_{5 \%}$} & Depth 1 & 30.8 & 29.2 & 2.57 & 31.9 & 51.8 & 31.4 & 31.3 & 318.8 \\
\hline & Depth 2 & 22.5 & 48.3 & 2.57 & 31.1 & 38.8 & 67.9 & 49.5 & 356.8 \\
\hline & Depth 3 & 22.6 & 25.7 & 9.08 & 10.3 & 2.57 & 20.5 & 18.8 & 332.7 \\
\hline
\end{tabular}

C16:0, palmitic acid; C18:3n6, linolenic acid; C18:2n9, linoleic acid; C18:0, stearic acid; C22:1n13, erucic acid; C23:0, tricosanic acid; C24:0, lignoceric acid; Total, sum of all lipids detected as mean \pm standard deviation. 
Soil PAs

PAs composing plant cell walls constitute the second most abundant organic constituent cycled in soil after CHs (Harkin, 1973). Sarkanen \& Ludwig (1971) reported that PAs with the structure $\mathrm{C}_{6}-\mathrm{C}_{3}$ (phenylpropene compounds such as $p$-hydroxycinnamic acid ( $p$-HC) and ferulic acid) were unique to vascular plants and not synthesized by soil microbial populations. As shown by Martens (2000a,b), the ester-linked PAs extracted from the soils studied were prevalent in the surface horizons and decreased rapidly with depth (Table 5). The pasture soil was found to contain the highest PA concentrations compared with the other two land-use soils. Very low levels of PAs in the former pasture soil converted to agricultural row crops suggest that crop residue-PAs were rapidly decomposed by tillage. The modified cinnamic acids, $p$-HC and ferulic acid are not considered part of the lignin structure of plants, but link $\mathrm{CHs}$ and proteins to plant lignins (Chen, 1992).

The PAs extracted by the lignin protocol following ester-linked PA extraction were related to the type of plant litter the soils received as forest, pasture and crops. The lignin concentration of the forest soil was statistically similar to the native pasture in the $0-4 \mathrm{~cm}$ soil depth, but lignin concentration was statistically higher in forest soil than the pasture and cropped soils in the deeper horizons (Table 6). Low amounts of lignin were found in the cropped soils with nondetectable amounts below the plow layer, while the forest soil had substantial amounts of lignin in the lower horizons. Recent research has shown that $\mathrm{C}$ allocation to belowground stocks by woody vegetation may be higher than previous research had documented (Smith et al., 1950) due to an annual fine root cycling turnover of 12 years with broad leaf species (Gaudinski et al., 2001), and may explain the higher amounts of lignin at deeper depths in the forest soil.

Martens (2002a) reported a significant relationship between soil ester-linked PA concentration and SOC, suggesting that the plant $\mathrm{C}$ retained in the soil, and soil aggregate stability after $84 \mathrm{~d}$ incubation was associated with the residue's initial PA concentration. Figure 2a shows a significant relationship between total soil PAs and SOC in the forest $(r=0.99 ; P<0.001)$ and pasture soils $(r=0.96 ; P<0.001)$. SOC content in the cropped soil showed no significant relationship with PAs of plant origin. The results of Martens (2002a) and the data presented here suggest that PAs are important for organic $\mathrm{C}$ induced soil aggregate stability and the formation of SOC-mineral complexes. Additional evidence supporting the PA-SOC relationship was published by Angers \& Giroux (1996), who determined by the use of $\delta^{13} \mathrm{C}$ analysis that soil aggregates are enriched in and stabilized by young labile organic matter derived from corn residue (rich source of PAs).

Plant cell wall material is composed of two or three structurally interacting networks (Carpita \& McCann, 2000). The fundamental framework of cellulose (B1-4 linked glucose) lies embedded in a second network of cross-linking polysaccharides (hemicellulose) with a third network composed of proteins (AAs) or phenylpropene units $\left(\mathrm{C}_{6}-\mathrm{C}_{3}\right.$ PAs) depending on the plant species (dicots vs. monocots). If the $\mathrm{C}$ present in forest and pasture soils is predominantly cell wall material,

Table 5 Major ester-linked phenolic acid profiles for the different land-use systems $(n=3)$

\begin{tabular}{|c|c|c|c|c|c|c|c|c|c|}
\hline \multirow[b]{2}{*}{ Land use } & \multirow[b]{2}{*}{ Depth $(\mathrm{cm})$} & \multicolumn{8}{|l|}{$\mathrm{mg} \mathrm{kg}^{-1}$} \\
\hline & & 4-OH-B & Van & 4-OH-Be & Vanillic & 4-OH-Cin & Syrin & Ferulic & Total \\
\hline \multirow[t]{3}{*}{ Forest } & $0-4$ & 60.1 & 75.2 & 56.2 & 119 & 156 & 137 & 60.6 & $874 \pm 360$ \\
\hline & $4-8$ & 43.0 & 19.0 & 40.0 & 45.4 & 69.7 & 48.5 & 32.9 & $449 \pm 8.4$ \\
\hline & $8-33$ & 16.0 & 30.0 & ND & 20.4 & ND & ND & ND & $66.4 \pm 4.8$ \\
\hline \multirow[t]{3}{*}{ Pasture } & $0-5$ & 69.3 & 75.7 & 57.8 & 138 & 681 & 200 & 294 & $1950 \pm 700$ \\
\hline & $5-13$ & 38.2 & 29.2 & 56.0 & 47.6 & 193 & 28.9 & 81.1 & $599 \pm 9.4$ \\
\hline & $13-33$ & 13.1 & ND & 24.8 & ND & ND & 47.7 & 20.3 & $106 \pm 4.6$ \\
\hline \multirow[t]{3}{*}{ Crop } & $0-20$ & 22.8 & 13.3 & ND & 23.4 & 107 & 33.3 & 27.5 & $175 \pm 16$ \\
\hline & $20-24$ & ND & ND & 1.79 & ND & 25.9 & ND & ND & $28.8 \pm 2.6$ \\
\hline & $24-38$ & ND & ND & ND & ND & ND & ND & ND & ND \\
\hline \multirow[t]{3}{*}{$\mathrm{LSD}_{5 \%}$} & Depth 1 & 12.8 & 15.6 & ND & 23.6 & 123 & 45.3 & 52.3 & 887 \\
\hline & Depth 2 & 2.31 & 5.62 & 12.5 & 6.32 & 25.6 & 10.3 & 42.5 & 435 \\
\hline & Depth 3 & 1.35 & ND & ND & ND & ND & ND & ND & 203 \\
\hline
\end{tabular}

4-OH-B, 4-hydroxybenzaldehyde; Van, vanillin; 4-OH-Be, 4-hydroxybenzoic acid; Vanillic, vanillic acid; 4-OH-Cin, 4-hydroxycinnamic acid; Syrin, syringic acid; Ferulic, ferulic acid; ND, not detected or not determined; Total, sum of all phenolic acids detected as mean \pm standard deviation. 
Table 6 Major lignin phenolic acid profiles for the different land-use systems $(n=3)$

\begin{tabular}{|c|c|c|c|c|c|c|c|}
\hline \multirow[b]{2}{*}{ Land use } & \multirow[b]{2}{*}{ Depth $(\mathrm{cm})$} & \multicolumn{6}{|l|}{$\mathrm{mg} \mathrm{kg}^{-1}$} \\
\hline & & Vanillin & AcetoVan & Vanillic & Syringald & AcetoSyrin & Total \\
\hline \multirow[t]{3}{*}{ Forest } & $0-4$ & 1644 & 1219 & 1093 & 2727 & 1091 & $8373 \pm 2256$ \\
\hline & $4-8$ & 914.4 & 742.4 & 721.6 & 1719 & 699.9 & $5272 \pm 976$ \\
\hline & $8-33$ & 328.8 & 303.4 & 293.5 & 581.5 & 294.8 & $1994 \pm 540$ \\
\hline \multirow[t]{3}{*}{ Pasture } & $0-5$ & 996.9 & 626.2 & 828.7 & 1187 & 823.7 & $5090 \pm 1897$ \\
\hline & $5-13$ & 398.8 & 271.3 & 800.3 & 328.5 & 156.5 & $1500 \pm 756$ \\
\hline & $13-33$ & 201.5 & 123.6 & 130.3 & 188.9 & 110.3 & $910.3 \pm 352$ \\
\hline \multirow[t]{3}{*}{ Crop } & $0-20$ & 91.21 & 108.5 & 32.51 & 261.3 & 236.8 & $731.2 \pm 235$ \\
\hline & $20-24$ & 95.51 & 77.88 & 40.21 & 105.6 & 134.9 & $465.3 \pm 125$ \\
\hline & $24-38$ & ND & ND & ND & ND & ND & ND \\
\hline \multirow[t]{3}{*}{$\mathrm{LSD}_{5 \%}$} & Depth 1 & 236.6 & 397.6 & 287.3 & 998.7 & 356.9 & 3392 \\
\hline & Depth 2 & 223.7 & 356.7 & 423.6 & 658.9 & 236.7 & 2031 \\
\hline & Depth 3 & 231.2 & 156.9 & 162.3 & 435.6 & 110.3 & 1301 \\
\hline
\end{tabular}

AcetoVan, acetovanillone; Vanillic, vanillic acid; Syringald, syringaldehyde; AcetoSyrin, acetosyringone; ND, not detected or not determined; Total, sum of all PAs detected as mean \pm standard deviation.
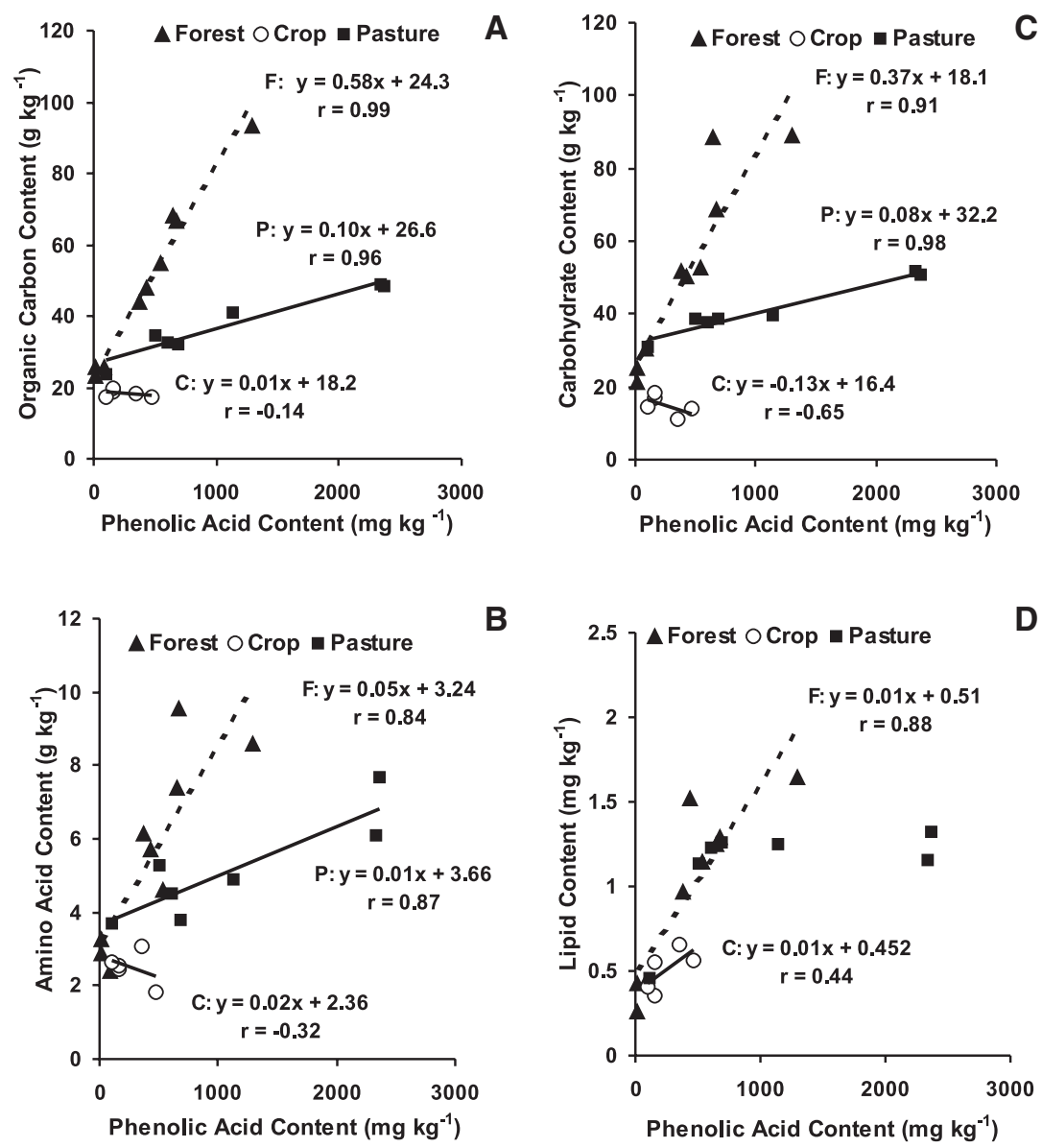

Fig. 2 The relationship between soil phenolic acid concentration and soil (a) organic carbon content, (b) amino acid concentration, (c) carbohydrate concentration and (d) lipid concentration for the different land uses. 
then strong relationships should exist between PA and the other components of SOC. Figures $2 b-d$ show that the important relationship between PAs and SOC content shown in Fig. 2a is also noted in the interaction of PAs and SOC measured as AA, CHs and LPs, respectively. Especially significant were the $\mathrm{PA}$ and $\mathrm{CH}$ relationship for the forest soil $(r=0.91 ; P<0.001)$ and the pasture soil $(r=0.98 ; P<0.001)$. These relationships were consistent with the hypothesis that the majority of the forest and pasture SOC was plant residue $\mathrm{C}$ related to the chemical structure of plant cell walls.

Since the soil PA concentration was correlated with the soil $C$ content, this suggests that the amount of plant residues remaining in soil could be estimated by the soil PA concentration as first proposed by Martens $(2002 a, b)$. It is of interest that even though the slopes of the regression lines in Fig. 2a differ for the pasture and forest soils, the $y$-intercept for both is approximately $25 \mathrm{gC}$. If the intercept value of $25 \mathrm{~g} \mathrm{C} \mathrm{kg}^{-1}$ soils is a measure of soil $\mathrm{C}$ not associated with plant-derived PAs, perhaps as microbial $C$, then an average of $67 \%$ $(0-4 \mathrm{~cm})(76 \mathrm{gC}-25 \mathrm{~g} \mathrm{C} / 76 \mathrm{gC})$ and $49 \%(4-8 \mathrm{~cm})$ of the forest SOC is plant residue C and $46 \%(0-5 \mathrm{~cm})$ and $25 \%$ $(5-13 \mathrm{~cm})$ of the pasture SOC is still remaining in the soils as plant residue. A similar value for plant-derived soil C was presented by Six et al. (2001), who reported that particulate organic material of plant origin accounted for $31 \%$ of the total C content in a $0-5 \mathrm{~cm}$ depth for a no-tillage winter wheat-fallow cropped sequence.
Volume of soil $C$

The surface horizons of the forest and pasture soils contain significantly greater organic $\mathrm{C}$ and $\mathrm{N}$ contents (Table 1) and, concomitantly, greater individual components of organic $\mathrm{C}$ compared with the cropped soil, but differences in biochemistry shown in Tables 2-6 need to be expressed on a volume basis for total content. The weighted equation 1 provides a component sum comparison on an $\mathrm{m}^{2}$ basis to $33 \mathrm{~cm}$ to encompass changes in the soils due to the different horizon thickness. The weighted comparison found that the forest soil had significantly greater $\mathrm{C}$ content (29\% > pasture and $46 \%>$ cropped soils) and $\mathrm{N}$ content $(19 \%>$ pasture and $42 \%>$ cropped soils) in the top $33 \mathrm{~cm}$. The values found here $(46 \%)$ closely match the percentage $C$ increase values presented by Guo \& Gifford (2002) for the land-use changes of cropped to secondary forest $(53 \%)$ and for the cropped to pasture land-use change ( $25 \%$ vs. $19 \%$ ).

The forest had the greatest concentration of extractable $\mathrm{C}$ as CHs, ester-linked PAs, lignin-PAs and LPs while the pasture soil had a greater AA concentration of the three land uses. During the dehydration-extraction procedure for AAs, $\mathrm{NH}_{3}$ can be lost from digested AAs and not accounted for by AA analysis. Recovering the amount of $\mathrm{NH}_{4}^{+}$released by the digestion process increased identified $\mathrm{N}$ recovered in the forest, pasture and cropped soils to $70 \%, 73 \%$ and $77 \%$, respectively. Conversion of the $\mathrm{CH}, \mathrm{AA}, \mathrm{PA}$ and $\mathrm{LP}$ composition to the respective $\mathrm{C}$ content (Table 7) found that $79 \%$ of the

Table 7 Carbon and nitrogen content and carbon component concentrations for the different land-use systems to a $33 \mathrm{~cm} \mathrm{depth*}$

\begin{tabular}{llll}
\hline & \multicolumn{2}{l}{ Land use $\left(\mathrm{kg} \mathrm{m}^{-2}\right)$} & \\
\cline { 2 - 4 } Carbon and compositions & Forest & Pasture & Crop \\
\hline Organic C & $44.8 \mathrm{~A}$ & $32.0 \mathrm{~B}$ & $24.0 \mathrm{C}$ \\
Total N & $4.20 \mathrm{~A}$ & $3.41 \mathrm{~B}$ & $2.42 \mathrm{C}$ \\
CH-C & $18.8 \mathrm{~A}(42 \%)^{\dagger}$ & $15.7 \mathrm{~A}(49 \%)$ & $12.2 \mathrm{~B}(51 \%)$ \\
AA-C & $6.79 \mathrm{~A}(15 \% \mathrm{C} ; 61 \% \mathrm{~N})^{\ddagger}$ & $7.13 \mathrm{~A}(22 \% \mathrm{C} ; 65 \% \mathrm{~N})$ & $4.32 \mathrm{~B}(18 \% \mathrm{C} ; 62 \% \mathrm{~N})$ \\
PA-C & $0.72 \mathrm{~A}(1.6 \%)$ & $0.41 \mathrm{~B}(1.3 \%)$ & $0.24 \mathrm{C}(1 \%)$ \\
LP-C & $1.03 \mathrm{~A}(2.3 \%)$ & $0.74 \mathrm{~B}(2.3 \%)$ & $0.70 \mathrm{~B}(2.9 \%)$ \\
Lignin-C & $4.48 \mathrm{~A}(10 \%)$ & $1.42 \mathrm{~B}(4.4 \%)$ & $0.04 \mathrm{~B}(0.02 \%)$ \\
Other-C & $13.0(29 \%)$ & $6.60(21 \%)$ & $6.50(27 \%)$
\end{tabular}

*The weighted $\mathrm{C}$ and $\mathrm{N}$ values were calculated: weighted mean $=\sum(T \times I \times$ bulk density $) / \sum \mathrm{Ti}$, where $T$ is the thickness of the horizon, $I$ is the quantity of the property of interest, bulk density is taken from Table 1 and Ti is the total thickness ( $33 \mathrm{~cm})$. Column values with a different letter designation are statistically different at the $5 \%$ level.

${ }^{\dagger}$ The value in parentheses indicates the percentage of total $\mathrm{C}$ the organic fraction composed. $\mathrm{CH}-\mathrm{C}=\sum(\mathrm{C}$ of individual $\mathrm{CH}) /$ organic $\mathrm{C}$; $\mathrm{AA}-\mathrm{C}=\sum\left(\mathrm{C}\right.$ of individual AA)/organic $\mathrm{C}$; $\mathrm{PA}-\mathrm{C}=\sum(\mathrm{C}$ of individual $\mathrm{PA}) /$ organic $\mathrm{C}$; FA-C $=\sum(\mathrm{C}$ of individual $\mathrm{FA})$ /organic $\mathrm{C}$; Lignin- $\mathrm{C}=\sum(\mathrm{C}$ of individual $\mathrm{PA})$ /organic $\mathrm{C}$; Other $=$ unaccounted for $\mathrm{C}$.

${ }^{\ddagger}$ The value in parenthesis indicates the percentage of total $\mathrm{N}$ the AA fraction composed calculated as AAs- $\mathrm{N}=\sum$ ( $\mathrm{N}$ of individual AA)/total N.

$\mathrm{CH}$, carbohydrate; AA, amino acid; PA, phenolic acid; FA, fatty acid. 
C content of the pasture soil could be identified as these compounds whereas $73 \%$ of the cropped soil and $71 \%$ forest soil $\mathrm{C}$ content were identified as $\mathrm{CHs}$, AAs, PAs and LPs. Of the soil $C$ accounted for, between 40 and $60 \%$ can be identified as $\mathrm{CHs}$ and PAs, which are identified by the use of biomarkers as originating from plant residue $\mathrm{C}$. The importance of $\mathrm{CH}$ and $\mathrm{PA}$ contributions to organic $\mathrm{C}$ content, separated using a StepWise regression analysis that reported the great variance, was first assigned to $\mathrm{CH}(r=0.94, P<0.001)$, then total PAs $(r=0.97, P<0.001)$ and finally LPs $(r=0.98, P<0.05)$.

Post \& Kwon (2000) reviewed the literature for potential $\mathrm{C}$ change in agricultural soils subjected to different land-use changes and found that the rate of $\mathrm{C}$ accumulation ranged from -47 to $310 \mathrm{~g} \mathrm{C} \mathrm{m}^{-2} \mathrm{yr}^{-1}$ during forest establishment (average $33.8 \mathrm{~g} \mathrm{C} \mathrm{m}^{-2} \mathrm{yr}^{-1}$ ) and from -90 to $113 \mathrm{~g} \mathrm{~m}^{-2} \mathrm{yr}^{-1}$ (average $33.2 \mathrm{gC}$ $\mathrm{m}^{-2} \mathrm{yr}^{-1}$ ) during pasture establishment. This study found that the $\mathrm{C}$ accumulation for the pasture to forest land-use conversion averaged $98.5 \mathrm{~g} \mathrm{C} \mathrm{m}^{-2} \mathrm{yr}^{-1}$ and the cropped to pasture land-use conversion averaged a gain of $61.5 \mathrm{gC} \mathrm{m}^{-2} \mathrm{yr}^{-1}$ with the cropped to secondary forest accounting for $160 \mathrm{~g} \mathrm{C} \mathrm{m}^{-2} \mathrm{yr}^{-1}$. Vesterdal et al. (2002) found that conversion of agricultural land to forest as oak (Quercus robur L.) or Norway spruce [Picea abies (L.) Karst] during the first 30 years increased the $C$ content in the $0-5 \mathrm{~cm}$ soil depth, but decreased soil C content in the $5-15$ and $15-25 \mathrm{~cm}$ depths in the mineral soil layers with increasing stand age. The forest in this study was established on pasture soil that had not experienced tillage, so the $\mathrm{C}$ inputs to the soil were not disturbed during the initial years of establishment. In contrast, the trees in the study documented by Vesterdal et al. (2002) were established following tillage to establish the stand and weeds were controlled by mechanical means for the first 3 years, which certainly limited the plant $C$ input during the initial years of the study. The comparison of the Vesterdal study with the results presented here emphasizes the importance of maintaining a permanent grass cover while establishing the secondary forest growth.

The results of different land use on the soil properties reported here suggest that the majority of organic $C$ in the surface $30 \mathrm{~cm}$ of undisturbed soils are present as plant residue in various stages of decomposition that increases soil aggregation. Organic $C$ retained in a soil is a function of the $\mathrm{N}$ content of the soil and as such SOC cannot be increased without increasing soil $\mathrm{N}$ content. The composition of the SOC in nondisturbed land use shows a strong relationship between the $\mathrm{CH}$ and PA markers and organic $\mathrm{C}$, and is consistent with the hypothesis that increased $\mathrm{C}$ is due to stabilized plant residue $\mathrm{C}$. Tillage increased the decomposition of plant residues and limited the stabilization of plant $C$ as noted by the lack of significant relationships for the components of the cropped soil SOC pool and soil properties. The practice of permanent pastures and afforestation of agricultural lands showed long-term potential for potential mitigation of atmospheric $\mathrm{CO}_{2}$.

\section{Acknowledgements}

The use of product or trade names in this publication is for descriptive purposes only and does not imply a guarantee or endorsement by the US. Department of Agriculture or the US Government. The authors want to thank the two anonymous reviewers for their contribution to the final manuscript.

\section{References}

Amato M, Ladd JN (1992) Decomposition of 14C-labelled glucose and legume material in soils: properties influencing the accumulation of organic residue $C$ and microbial biomass C. Soil Biology and Biochemistry, 24, 455-464.

Angers DA, Giroux M (1996) Recently deposited organic matter in soil water-stable aggregates. Soil Science Society of America Journal, 60, 1547-1551.

Arao T (1999) In situ detection of changes in soil bacterial and fungal activities by measuring $13 \mathrm{C}$ incorporation into soil phospholipid fatty acids from 13C acetate. Soil Biology and Biochemistry, 31, 1015-1020.

Baird BH, White DC (1985) Biomass and community structure of the abyssal microbiota determined from the ester-linked phospholipids recovered from Venezuela basin and Puerto Rico trench sediments. In: Benthic Ecology and Sedimentary Processes of Venezuela Basin - Past and Present, Vol. 68 (eds Young DK, Richardson MD), pp. 217-231. Elsevier, Amsterdam.

Beare MH, Cabrera ML, Hendrix PF et al. (1994) Aggregateprotected and unprotected organic matter pools in conventional- and no-tillage soils. Soil Science Society of America Journal, 58, 787-795.

Biederbeck VO, Janzen HH, Campbell CA et al. (1994) Labile soil organic matter influenced by cropping practices in an arid environment. Soil Biology and Biochemistry, 26, 1647-1656.

Blake GR, Hartge KH (1986) Bulk density. In: Methods of Soil Analysis, Part 1 (ed. Klute A), pp. 383-409. American Society of Agronomy, Madison, WI.

Bolin B, Sukumar R (2000) Global perspective. In: Land Use, Land Use Change, and Forestry (eds Watson RT, Noble IR, Bolin B, Ravindranath NH, Verardo DJ, Dokken DJ), Cambridge University Press, Cambridge, UK.

Bossuyt H, Six J, Hendrix PF (2002) Aggregate-protected carbon in no-tillage and conventional tillage agroecosystems using carbon-14 labeled plant residue. Soil Science Society of America Journal, 66, 1965-1973.

Brady NC, Weil RR (1999) The Nature and Properties of Soils, Twelfth Edition. Prentice-Hall, New York.

Bremer E, Janzenm HH, Johnston AM (1994) Sensitivity of total, light fraction and mineralizable organic matter on management practices in a Lethbridge soil. Canadian Journal of Soil Science, 74, 131-138. 
Bruce JP, Frome M, Haites E et al. (1999) Carbon sequestration in soils. Journal of Soil and Water Conservation, 54, 382-386.

Capriel P, Harter P, Stephenson D (1992) Influence of management on the organic matter of a mineral soil. Soil Science, 153, 122-128.

Carpita N, McCann M (2000) The cell wall. In: Biochemistry and Molecular Biology of Plants (eds Buchanan BB et al.), American Society of Plant Physiologists, Rockville, MD.

Chen CL (1992) Nitrobenzene and cupric oxide oxidations. In: Methods in Lignin Chemistry (eds Lin SY, Dence CW), pp. 301321. Springer-Verlag, New York.

Cheshire MV, Chapman SJ (1996) Influence of the N and P status of plant material and of added $\mathrm{N}$ and $\mathrm{P}$ on the mineralization of C from 14C-labelled ryegrass in soil. Biology Fertility of Soils, 21, 166-170.

Christensen BT (1992) Physical fractionation of soil and organic matter in primary particle size and density separates. Advances in Soil Science, 20, 1-90.

Davidson EA, Ackerman IL (1993) Changes in soil carbon inventories following cultivation of previously untilled soils. Biogeochemistry, 20, 161-193.

Davidson EA, Chorover J, Dail DB (2003) A mechanism of abiotic immobilization of nitrate in forest ecosystems: the ferrous wheel hypothesis. Global Change Biology, 9, 228-236.

Enriquez S, Duarte CM, Sand-Jensen K (1993) Patterns in decomposition rates among photosynthetic organisms: the importance of detritus C:N:P content. Oecologia, 94, 457-471.

Follett RF, Schimel DS (1989) Effect of tillage practices on microbial biomass dynamics. Soil Science Society of America Journal, 53, 1091-1096.

Frostegard A, Baath E, Tunlid A (1993) Shifts in the structure of soil microbial communities in limed forests as revealed by phospholipid fatty acid analysis. Soil Biology and Biochemistry, 25, 723-730.

Gaudinski JB, Trumbore SE, Davidson EA et al. (2001) The age of fine-root carbon in three forests in the eastern United States measured by radiocarbon age. Oceologia, 129, 420-429.

Gee GW, Bauder JW (1986) Particle-size analysis. In: Methods of Soil Analysis, Part 1 (ed. Klute A), pp. 383-409. American Society of Agronomy, Madison, WI.

Guo LB, Gifford RM (2002) Soil carbon stocks and land use change: a meta analysis. Global Change Biology, 8, 345-360.

Gupta RK, Rao DLN (1994) Potential of wasteland for sequestrating carbon by reforestation. Current Science, 66, 378-380.

Harkin JM (1973) Lignin (Forage plants). In: Chemistry and Biochemistry of Herbage (eds Butler GW, Bailey RW), pp. 323373. Academic Press, New York.

Herman WA, McGill WB, Dormaar JF (1977) Effects of initial chemical composition on decomposition of roots of three grass species. Canadian Journal of Soil Science, 57, 205-215.

Jenkinson DS (1977) Studies on the decomposition of plant materials in soil. V. Journal of Soil Science, 28, 424-434.

Keeney DR, Nelson DW (1982) Nitrogen-inorganic forms. In: Methods of Soil Analysis Part 2 (eds Page AL et al.), pp. 643-698. American Society of Agronomy, Madison, WI.

Kemper WD, Rosenau RC (1986) Aggregate stability and size distribution. In: Methods of Soil Analysis Part 1 (ed. Klute A), pp. 413-424. American Society of Agronomy, Madison, WI.
Martens DA (2000a) Plant residue biochemistry regulates soil carbon cycling and carbon sequestration. Soil Biology and Biochemistry, 32, 361-369.

Martens DA (2000b) Management and crop residue influence soil aggregate stability. Journal of Environmental Quality, 29, $723-727$.

Martens DA (2002a) Change in soil phenolic acid composition during decomposition of plant biomass. Soil Science Society of America Journal, 66, 1240-1248.

Martens DA (2002b) Identification of phenolic acids isolated from plants and soils. Soil Science Society of America Journal, 66, 1857-1867.

Martens DA, Frankenberger WT Jr (1992) Decomposition of bacterial saccharides in soil and their influence on soil structure. Biology and Fertility of Soils, 13, 65-73.

Martens DA, Loeffelmann KL (2002) Improved accounting of carbohydrate carbon from plants and soils. Soil Biology and Biochemistry, 34, 1393-1399.

Martens DA, Loeffelmann KL (2003) Soil amino acid composition quantified by acid hydrolysis and anion chromatography pulsed amperometry. Journal of Agriculture and Food Chemistry, 51, 6521-6529.

Murty D, Kirschbaum MUF, McMurtrie RE et al. (2002) Does conversion of forest to agricultural land change soil carbon and nitrogen? A review of the literature. Global Change Biology, 8, 105-123.

Neely CL, Beare MH, Hargrove WL et al. (1991) Relationships between fungal and bacterial substrate-induced respiration, biomass and plant residue decomposition. Soil Biology and Biochemistry, 23, 947-954.

Oades JM (1988) The retention of organic matter in soils. Biogeochemistry, 5, 35-80.

Oades JM, Wagner GH (1971) Biosynthesis of sugars in soils incubated with 14C glucose and 14C dextran. Soil Science Society of America Proceedings, 35, 914-917.

Post WM, Kwon KC (2000) Soil carbon sequestration and landuse change: processes and potential. Global Change Biology, 6, 317-327.

Post WM, Mann LK (1990) Changes in soil organic carbon and nitrogen as a result of cultivation. In: Soils and the Greenhouse Effect (ed. Bouwman AF), pp. 401-406. John Wiley, New York.

Reedy TE (1999) Land use effects on the properties of a Sharpsburg soil in southeastern Nebraska. MS thesis, University of Nebraska, College of Agriculture, Lincoln, Nebraska, 120 pp.

Reed EC, Dreeszen FH (1965) Revision of the classification of the Pleistocene deposits of Nebraska. Nebraska Geological Survey Bulletin, 23, 65 pp.

Sarkanen KV, Ludwig CH (1971) Lignins. Wiley-Interscience, New York.

Sautter HE (1982) Soil Survey of Otoe County, Nebraska. SCS, USDA in cooperation with the University of Nebraska, Conservation and Survey Division.

Schlesinger WH (1985) Changes in soil carbon storage and associated properties with disturbance and recovery. In: The Changing Carbon Cycle A Global Analysis (eds Trabalka JR, Reichle DE), Springer, New York.

Six J, Callewaert P, Lenders S et al. (2002) Measuring and understanding carbon storage in afforested soils by physical 
fractionation. Soil Science Society of America Journal, 66, 19811987.

Six J, Guggenberger G, Paustian K et al. (2001) Sources and composition of soil organic matter fractions between and within soil aggregates. European Journal of Soil Science, 52, 607618.

Smith GD, Allway WH, Riecken F (1950) Prairie soils of the upper Mississippi valley. Advances in Agronomy, 2, 157-205.

Sommerville C, Browse J, Jaworski JG et al. (2000) Lipids. In: Biochemistry and Molecular Biology of Plants (eds Buchanan BB), American Society of Plant Physiologists, Rockville, MD.

Sowden FJ, Ivarson KC (1962) Decomposition of forest litters. III. Changes in the carbohydrate constituents. Plant and Soil, 16, 389-400.

Vesterdal L, Ritter E, Gundersen P (2002) Changes in soil organic carbon following afforestation of former arable land. Forest Ecology and Management, 169, 137-147.

Wang TSC, Hwang PT, Chen CY (1971) Soil lipids under various crops. Soil Science Society of America Proceedings, 35, $584-587$.
White DC, Davies WM, Nickels JS et al. (1979) Determination of the sedimentary microbial biomass by extractable lipid phosphate. Oecologia, 40, 51-62.

Whitehead D, Dibb CH, Hartley RD (1983) Bound phenolic compounds in water extracts of soils, plant roots, and leaf litter. Soil Biology and Biochemistry, 15, 133-136.

Wright SF, Anderson RL (2000) Aggregate stability and glomalin in alternative crop rotations for the central Great Plains. Biology and Fertility of Soils, 31, 249-253.

Zelles L, Bai QY (1993) Fractionation of fatty acids derived from soil lipids by solid phase extraction and their quantitative analysis by GC-MS. Soil Biology and Biochemistry, 25, 495-507.

Zelles L, Bai QY, Beck T et al. (1992) Signature fatty acids in phospholipids and lipopolysaccharides as indicators of microbial biomass and community structure in agricultural soils. Soil Biology and Biochemistry, 24, 317-323.

Zelles L, Bai QY, Rackwitz R et al. (1995) Determination of phospholipid- and lipopolysaccharide-derived fatty acids as an estimate of microbial biomass and community structures in soils. Biology and Fertility of Soils, 19, 115-123. 